order to study its structural damping without having to wait for a suitable wind to excite oscillations, thrust units were attached to the top of the chimney and fired. The vibrations induced were measured in two perpendicular planes by means of piezo-electric accelerometers.

The Division's work on the establishment of standards of high pressure continues, and the new method of eliminating errors due to distortions of the pressure balances has now been used up to 3,000 atmospheres. This technique enables high pressures to be measured to an accuracy of a few parts in 100,000.

The Ship Division has extended its study of the conditions in which cavitation occurs from propellers to other hydrofoil devices like stabilizers and hydrofoil vessels. The Lithgow water tunnel has been modified for this purpose and force and acoustic measurements are now being made in it on a model of a fin for a ship roll-stabilizer. A new threecomponent balance has been developed and the model is mounted on this. Acoustic measurements are made with a hydrophone placed in a water-filled chamber in contact with a side window of the tunnel, the output being fed through an amplifier to a harmonic analyser for frequency analysis of the acoustic spectrum.

In order to calculate the motions of a ship in rough water, the values of certain coefficients are needed. The entrained water coefficient and the damping coefficient are functions of the hull shape and can be estimated theoretically, but there are few experimental results available to check the accuracy of the estimates. The Division is carrying out experiments to measure these coefficients for a number of different hull forms. The problem is simplified by restricting the motion to one plane and force-pitching the model in calm water by a system of rotating weights. A known cyclic variation of pitching couple produces an angle of pitch and a coupled vertical motion of the centre of gravity. Measurements are made of the angle of pitch, the heave of the centre of gravity and the phase relationship between these motions and the applied couple. 'These are recorded continuously throughout an experiment. The frequency of the applied couple is variable over a wide range and includes the resonant frequency. A. J. GarratT

\title{
OBITUARY
}

\section{Prof. Marinus Van den Ende}

Ar the time of his death on June 4, at the early age of forty-five, Marinus Van den Ende was professor of bacteriology and dean of the Faculty of Medicine in the University of Cape Town, where he had earlier studied and graduated. He had come to England in 1937 with a John Lucas Walker Studentship, to work in the Department of Pathology at Cambridge, where Prof. H. R. Dean introduced him to me in the autumn of 1938 . Even my short talk with him, at that first meeting, had made me glad to be able to respond to a suggestion that he might move to the National Institute for Medical Research, then at Hampstead, for the remainder of his second year.

Early in 1939, when he had been with us there for only three or four months, he had won such high regard from all by his character and personality, as well as by the brilliant promise which he showed in research, that a proposal to keep him, if possible, as a member of our staff was received with general enthusiasm. He felt at that time that his first duty was to South Africa; but he was able to obtain leave to extend his stay with us until the end of that year. In the last week of August the news of the Russo-German pact drove a number of us hurriedly home from the European Continent. Van den Ende had meanwhile married a young lady from South Africa, whom he had met again in London; but I found him now waiting anxiously for my return, in order to offer himself for the position on our staff which he had earlier felt obliged to refuse. He and his young wife had seen clearly what was coming, and both were eager to be with us in the coming world conflict. So he stayed throughout the War, doing splendid service, some of it involving serious personal risk.

Van den Ende first became an active member of a team working on methods for preventing aerial crossinfections in hospitals. Then, with Dr. Christopher Andrewes and the late Dora Lush, he was engaged in researches undertaken with some urgency, and having as their object the production of a safe and effective method of vaccination against typhus-an enterprise in the course of which every member of the team suffered, sooner or later, from an attack of the disease. Later he visited the armies in North Africa, with the rank of major in the R.A.M.C., to make a controlled trial of certain potential chemotherapeutic agents for the treatment of typhus. His final and most distinguished contribution to the war effort was the organization and direction, on behalf of the Medical Research Council and the War Office, of a special research unit, created on the Wellcome Foundation's farm estate at Frant, in Kent, for the production of a vaccine against the very dangerous 'scrub typhus', which the armies had encountered in the jungles of Burma and the Far East.

In 1945 he was free at last to return to Cape Town, where he was appointed professor of bacteriology, and where, in the years that followed, he made a rapidly growing reputation as a coming leader in research on the viruses, and as an influential teacher and an able organizer. He was on a visit to Melbourne some four years ago, to work for six months with Sir Macfarlane Burnet, when signs appeared of the illness which, though its progress was retarded by an operation and other forms of therapy, advanced to its inevitable end. With astonishing courage he used the intervals of temporary relief, between successive courses of prostrating treatment, to carry on his researches and his teaching, to such effect that his reputation in the world as a virologist continued still to grow, while he was persuaded further to accept the duties of dean.

Looking at what Van den Ende had thus achieved in a life cut short so early, and so marred by illness in what should have been its crowning years, his friends are left wondering what heights he might have attained had fate been kind, and mourning the loss to the world and to the community of science. Their sympathy goes to his widow, facing the situation with a courage worthy of him, and to their four children.
H. H. Dale 